From the 21st Century B.c. to the 21st Century A.D. 



\section{From the 21st Century B.C. to the 21st Century A.D.}

Proceedings of the International Conference on Sumerian Studies Held in Madrid 22-24 July 2010

edited by

Steven Garfinkle and Manuel Molina

Winona Lake, Indiana

Eisenbrauns

2013 
(C) 2013 by Eisenbrauns Inc.

All rights reserved

Printed in the United States of America

www.eisenbrauns.com

\section{Library of Congress Cataloging-in-Publication Data}

International Conference on Neo-Sumerian Studies (2010: Madrid, Spain)

From the 21st century B.c. to the 21st century A.D. : proceedings of the International Conference on Neo-Sumerian Studies held in Madrid 22-24 July 2010 / edited by Steven J. Garfinkle and Manuel Molina.

$$
\text { pages } \mathrm{cm}
$$

Includes bibliographical references and indexes.

ISBN 978-1-57506-296-9 (hardback : alkaline paper)

1. Ur (Extinct city)—Civilization-Congresses. 2. Sumerian language-

Texts-Congresses. 3. Babylonia-History-Congresses. 4. Iraq-HistoryTo 634-Congresses. 5. Iraq-Antiquities-Congresses. I. Garfinkle,

Steven J. II. Molina, Manuel. III. Title.

DS70.5.U7I56 2010

$935^{\prime} .501-\mathrm{dc} 23$

2013040752

The paper used in this publication meets the minimum requirements of the American National Standard for Information Sciences-Permanence of Paper for Printed Library Materials, ANSI Z39.48-1984.@ ${ }^{\mathrm{TM}}$ 
We dedicate this volume to Hartmut Waetzoldt with great affection from his friends and colleagues. Hartmut's skills and energy as an Assyriologist are matched by his devotion to the study of the Third Dynasty of Ur. The numerous authors in this volume have all benefited from his many contributions to our understanding of this period over the last four decades. 
